\title{
Rapid Procedure for the Approximate Determination of the Deoxyribonucleic Acid Base Composition of Micrococci, Staphylococci, and Other Bacteria
}

\author{
SOLTI A. MEYER AND KARL H. SCHLEIFER \\ Lehrstuhl für Mikrobiologie, Technische Universität München, 8 München 2, Germany
}

A simple and rapid procedure for the isolation of bacterial deoxyribonucleic acid is described. The deoxyribonucleic acid preparations are pure enough to determine the base composition by ultraviolet spectroscopy.

Currently the most reliable test for the separation of staphylococci and micrococci is either an analysis of their deoxyribonucleic acid (DNA) base composition or the determination of their cell wall components. Since it is rather laborious and time consuming to determine such properties, these procedures have to be simplified for routine use in the laboratory.

With regard to base composition, the isolation of pure DNA is wearysome, and optimal conditions for cell lysis often have to be found empirically. In addition, a large amount of cells needs to be harvested to gain sufficient DNA.

A simple procedure for the isolation of DNA is described. The resulting DNA is pure enough to allow a reasonably accurate determination of its base composition by the method of Ulitzur (17). Since the DNA base composition of micrococci (65 to $75 \mathrm{~mol} \%$ guanine plus cytosine $[\mathrm{G}+\mathrm{C}])$ differs greatly from that of staphylococci ( 30 to $40 \mathrm{~mol} \% \mathrm{G}+\mathrm{C}$ ), even an approximate determination of this value is sufficient to distinguish between these two genera.

To isolate the DNA, the cells of a $300-\mathrm{ml}$ culture grown overnight are harvested and suspended in a small amount $(1 \mathrm{ml})$ of salineethylenediaminetetraacetate buffer $(0.15 \mathrm{NaCl}$, $0.1 \mathrm{M}$ ethylenediaminetetraacetate, $\mathrm{pH}$ 8.0). Proteinase $\mathrm{K}(50 \mu \mathrm{g} / \mathrm{ml})$ is added to eliminate nuclease activity. After being mixed with glass beads (diameter, 0.17 to $0.18 \mathrm{~mm}$ ) until a viscous consistency is reached, the cells are ground in a cell mill (Vibrogen cell mill, Bühler, Tübingen) for $10 \mathrm{~min}$. The cell constituents are then separated from the glass beads by a wash with $10 \mathrm{ml}$ of saline-ethylenediaminetetraacetate buffer and suction through a coarse, sintered filter.

A 5-ml volume of the filtrate is made $1 \mathrm{M}$ with respect to $\mathrm{NaCl}$ by adding $0.3 \mathrm{~g}$ of $\mathrm{NaCl}$. A 2 -ml volume of a $4 \%$ cetyltrimethylammonium bromide $(\mathrm{CTAB})$ solution in $1 \mathrm{M} \mathrm{NaCl}$ and 2.0 $\mathrm{ml}$ of isopropanol are also added. The mixture is shaken vigorously with 1 volume of chloro- form-isoamyl alcohol $(24: 1, \mathrm{vol} / \mathrm{vol})$ until a thick, stable emulsion is formed. After a precooling to $0 \mathrm{C}$ and centrifugation for $30 \mathrm{~min}$ at $12,000 \times g$, the clear upper phase containing the nucleic acids and devoid of interfering pigments is pipetted off, and $2 \mathrm{ml}$ of CTAB solution is added. Upon dilution with 1 volume of distilled water, the CTAB salts of the nucleic acids precipitate and are collected by centrifugation. The pellet is dissolved in a few milliliters of $1 \mathrm{M}$ $\mathrm{NaCl}$, and the CTAB is removed upon being shaken once with 1 volume of chloroform. The sodium salt of the DNA is precipitated out of the aqueous phase by the addition of 0.6 volume of isopropanol and collected by centrifugation. A few milliliters of saline-citrate buffer $(0.15 \mathrm{M}$ $\mathrm{NaCl}$ plus $0.015 \mathrm{M}$ trisodium citrate, $\mathrm{pH} 7.0$ ) is layered over the pellet until it becomes translucent. The wash water is then discarded, and the pellet is dissolved in $2 \mathrm{ml}$ of saline-citrate buffer.

The protein content of the DNA preparations is determined by the method of Lowry et al. (12) and is less than $50 \mu \mathrm{g} / \mathrm{ml}$, i.e., less than $2 \%$. By selectively precipitating the DNA with CTAB (6) and isopropanol (13), the ribonucleic acid and polysaccharide content can also be strongly reduced. In fact, by fractionating our DNA preparation over a Sephadex B4 column by the method of Zadražil et al. (18), only a minimal amount of ribonucleic acid and protein contamination was found. Thus, the DNA is sufficiently pure for an estimation of its base composition from the 245-nm/270-nm absorption ratio by the method of Ulitzur (17).

The DNA base composition of several strains has been examined by the isolation procedure proposed here. The results are listed in Table 1. The deviation in base composition between the proposed method and thermal denaturation values derived from the literature is only $\pm 3 \mathrm{~mol} \%$ $\mathrm{G}+\mathrm{C}$. Therefore, a distinction between micrococci and staphylococci can easily be made. Moreover, it should be pointed out that the 
TABLE 1. Comparison of the base compositions of DNA isolated and determined by the rapid procedure with those determined by classical methods ${ }^{a}$

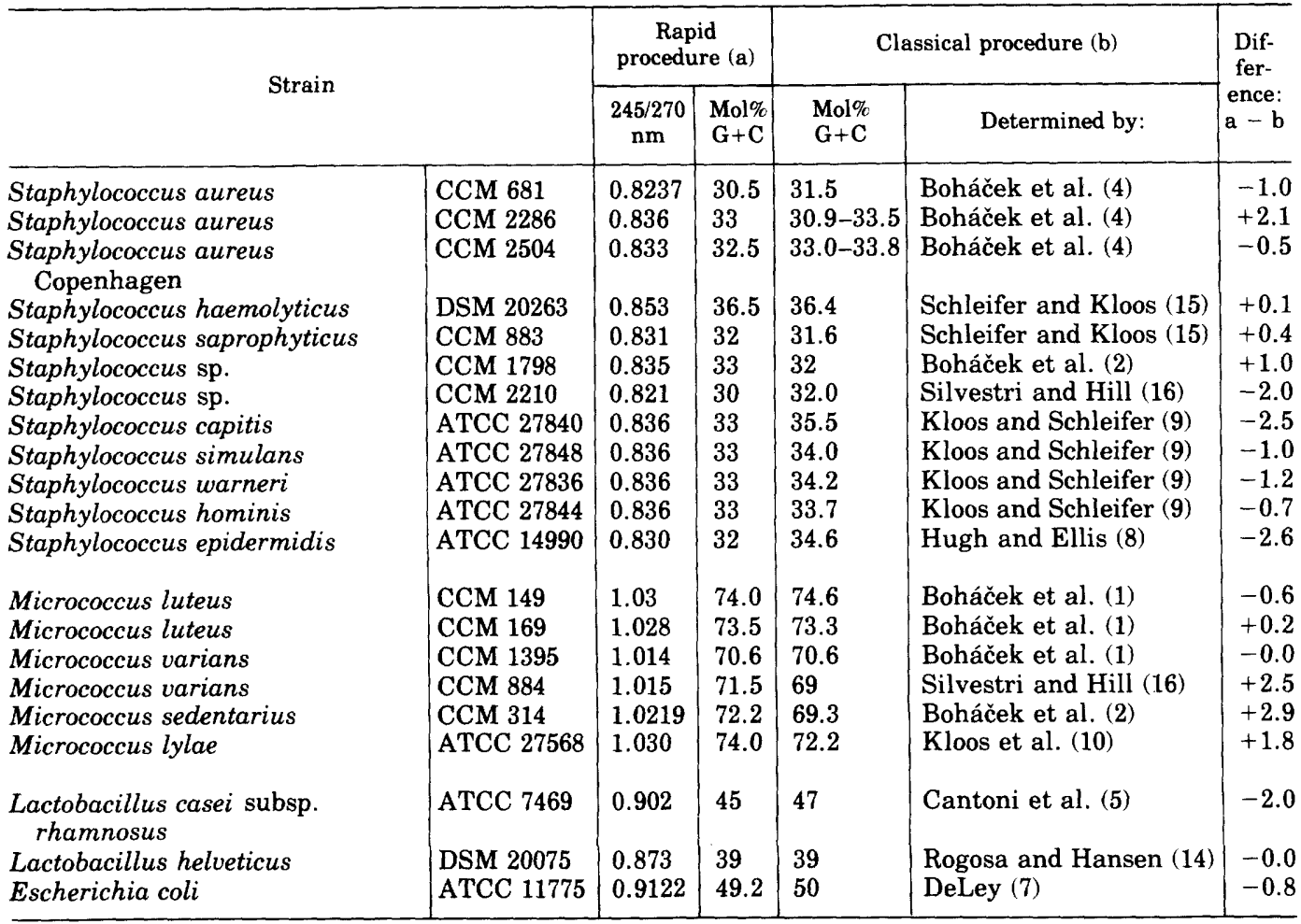

a Abbreviations: ATCC, American Type Culture Collection, Rockville, Md.; CCM, Czechoslovak Collection of Microorganisms, Brno; DSM, Deutsche Sammlung für Mikroorganismen, Göttingen.

deviation of $\pm 3 \mathrm{~mol} \% \mathrm{G}+\mathrm{C}$ is not necessarily a characteristic of the proposed rapid method but may be due to the fact that the literature values are derived from different laboratories. Several examples can be found (11) in which different authors report $\mathrm{G}+\mathrm{C}$ values that deviate up to $\pm 5.9 \mathrm{~mol} \% \mathrm{G}+\mathrm{C}$ for the same strain despite identical methods of $\mathrm{G}+\mathrm{C}$ determination.

In our proposed method, the isolation of DNA can be carried out in a test tube after the cells have been broken up with glass beads. Only 5 $\mathrm{ml}$ of a concentrated, crude cell extract is required, and the DNA from at least eight strains can be isolated from the cell extracts in about 4 h. Not only is less than $1 \mathrm{~g}$ (wet weight) of cells sufficient for DNA isolation, but also no problems with regard to cell lysis arise. In a few carefully chosen steps, DNA can be isolated that is sufficiently free from ribonucleic acid, polysaccharides, and proteins. The determination of the base composition by the method of Ulitzur (17) is accomplished in only a few minutes so that, together with the proposed rapid DNA isolation procedure, an ideal combination for routine determinations of the $\mathrm{G}+\mathrm{C}$ content of a large number of strains is given.
This method not only is satisfactory for distinguishing between micrococci and staphylococci but also gives equally good results when the DNAs of other organisms, such as lactobacilli or Escherichia coli, are compared (Table 1). Thus, this procedure can also be applied successfully to other bacteria.

\section{REPRINT REQUESTS}

Address reprint requests to: Dr. Karl Heinz Schleifer, Lehrstuhl für Mikrobiologie, Technische Universität. München, 8 München 2, Arcisstrasse 21, BRD.

\section{LITERATURE CITED}

1. Boháček, J., M. Kocur, and T. Martinec. 1967. DNA base composition and taxonomy of some micrococci. J. Gen. Microbiol. 46:369-379.

2. Boháček, J., M. Kocur, and T. Martinec. 1968. Deoxyribonucleic acid base composition of some marine and halophilic micrococci. J. Appl. Bacteriol. 31:215-219.

3. Boháček, J., M. Kocur, and T. Martinec. 1970. DNA base composition of some Micrococcaceae. Microbios 6:85-91.

4. Boháček, J., M. Kocur, and T. Martinec. 1973. Deoxyribonucleic acid base composition of staphylococci. Zentralbl. Bakteriol. Parasitenkd. Infektionskr. Hyg. Abt. 1 Orig. Reihe A 223:488-495.

5. Cantoni, C., L. R. Hill, and L. G. Silvestri. 1965. Deoxy- 
ribonucleic acid base composition of some members of the subgenera Betabacterium and Streptobacterium. Appl. Microbiol. 13:631-633.

6. Darby, K. G., A. S. Jones, J. F. Kennedy, and R. T. Walker. 1970. Isolation and analysis of the nucleic acids and polysaccharides from Clostridium welchii. J. Bacteriol. 103:159-165.

7. DeLey, J. 1970. Reexamination of the association between melting point, buoyant density, and chemical base composition of deoxyribonucleic acid. J. Bacteriol. 101:738-754.

8. Hugh, R., and M. A. Ellis. 1968. The neotype strain for Staphylococcus epidermidis. (Winslow and Winslow 1908) Evans 1916. Int. J. Syst. Bacteriol. 18:231-239.

9. Kloos, W. E., and K. H. Schleifer. 1975. Isolation and characterization of staphylococci from human skin. II. Descriptions of four new species: Staphylococcus warneri, Staphylococcus capitis, Staphylococcus hominis, and Staphylococcus simulans. Int. J. Syst. Bacteriol. 25:62-79.

10. Kloos, W. E., T. G. Tornabene, and K. H. Schleifer. 1974. Isolation and characterization of micrococci from human skin, including two new species: Micrococcus lylae and Micrococcus kristinae. Int. J. Syst. Bacteriol. 24:79-101.

11. Kocur, M., T. Bergan, and N. Mortensen. 1971. DNA base composition of Gram-positive cocci. J. Gen. Microbiol. 69:167-183.
12. Lowry, O. H., N. J. Rosebrough, A. L. Farr, and R. J. Randall. 1951. Protein measurement with the Folin phenol reagent. J. Biol. Chem. 193:265-275.

13. Marmur, J. 1961. A procedure for the isolation of deoxyribonucleic acid from microorganisms. J. Mol. Biol. 3:208-218.

14. Rogosa, M., and P. A. Hansen. 1971. Nomenclatural considerations of certain species of Lactobacillus Beijerinck. Int. J. Syst. Bacteriol. 21:177-186.

15. Schleifer, K. H., and W. E. Kloos. 1975. Isolation and characterization of staphylococci from human skin. I. Amended descriptions of Staphylococcus epidermidis and Staphylococcus saprophyticus and descriptions of three new species: Staphylococcus cohnii, Staphylococcus haemolyticus, and Staphylococcus xylosus. Int. J. Syst. Bacteriol. 25:50-61.

16. Silvestri, L. G., and L. R. Hill. 1965. Agreement between deoxyribonucleic acid base composition and taxonomic classification of gram-positive cocci. J. Bacteriol. 90:136-140.

17. Ulitzur, S. 1972. Rapid determination of DNA base composition by ultraviolet spectroscopy. Biochim. Biophys. Acta 272:1-11.

18. Zadražil, S., J. Satava, and Z. Somová. 1973. Isolation procedure for bacteria DNA based on gel permeation chromatography on a Sepharose column. J. Chromatogr. 91:451:458. 